Chirurgia (2020) 115: 365-372

No. 3, May - June

Copyright@ Celsius

http://dx.doi.org/10.21614/chirurgia.115.3.365

\title{
Parameters for Predicting Tumour Response Following Neoadjuvant Chemoradiotherapy for Patients with Rectal Cancer
}

\author{
Iustinian Bengulescu, Petru Radu*, Cristian lorga, Mircea Bratucu, Costin Pasnicu, Dragos Garofil, \\ Florian Popa, Victor Strambu
}

Department of Surgery, Carol Davila Clinical Hospital of Nephrology, Bucharest, Romania

*Corresponding author:

Petru Radu, MD

Department of Surgery

Carol Davila Clinical Hospital of

Nephrology, Bucharest, Romania

E-mail: drradupetru@yahoo.com
Received: 20.03.2020

Accepted: 27.04 .2020

\section{Rezumat}

Parametrii de predicție a răspunsului tumoral după radio-chimioterapia neoadjuvantă la pacienții cu cancer rectal

Introducere:Răspunsul patologic tumoral după radio-chimioterapia neoadjuvantă poate varia de la răspuns patologic complet până la „downstaging tumoral" sau lipsa răspunsului. Scopul nostru a fost de a evalua parametrii care ar putea prezice gradul de răspuns tumoral pentru pacienții cu cancer rectal.

Metodă:Am realizat un studiu retrospectiv analizând documentația pacienților care au fost tratați în clinica noastră între 2014-2018 după radio-chimioterapie neoadjuvantă.

Rezultate:Un număr de 98 de pacienți au fost incluşi în studiu, 66 de sex masculin $(67,3 \%)$ şi 32 de sex feminin (32,7\%). Vârsta medie a fost de 64,6 ani (39-87). Supraviețuirea la 48 de luni a fost de $81,63 \%$ şi rata de supraviețuire „cancer free” la 48 de luni a fost de $69,38 \%$. Gradientul de diferentiere tumoral a fost considerat parametru statistic semnificativ în prezicerea răspunsului tumoral. Tumorile cu probabilitatea cea mai mare de a răspunde la radiochimioterapie au fost din grupa G1 şi G2. Tumorile din stadiul T4 în comparație cu stadiile mai mici au prezentat cea mai redusă proporție în obținerea răspunsului patologic complet. Valori crescute ale CEA de asemenea pot anticipa un răspuns tumoral slab.

Concluzie:Studiul nostru a evidențiat faptul că parametrii tumorali cum ar fi stadiul T, stadiul N, scorul G dar şi markeri biologici precum valorile CEA pot fi folosiți cu valoare predictivă pentru analiza răspunsului patologic tumoral după radio-chimioterapia neoadjuvantă.

Cuvinte cheie: cancer rectal, radio-chimioterapie neaodjuvantă, radio-chimmioterapie, parametri de predicție 


\section{Abstract}

Introduction: Pathologic response following neoadjuvant chemoradiotherapy (nCRT) can vary from pathologic complete response (pCR), to tumour downstaging or minimum to no response. Our goal was to evaluate the parameters that could predict response to neoadjuvant therapy for patients with rectal cancer.

Method. We performed a retrospective study and reviewed the medical documentation for patients that received treatment for rectal cancer in our surgical department between 2014-2018 and received nCRT.

Results:A total of 98 patients were included in the study. 66 patients were males $(67,3 \%)$ and 32 were females (32,7\%). The mean age was 64,6 (39-87). The 48 months overall survival rate was $81,63 \%$ and the 48 months disease-free survival rate was $69,38 \%$. Tumour grading was considered as a statistically significant parameter for evaluating the pathologic response. The tumours most likely to respond to radio-chemotherapy were G1 or G2 grade. T4 tumours compared with lesser T stages were less likely to achieve pathologic complete response. Elevated CEA levels predicted a poor pathologic response to $\mathrm{nCRT}$.

Conclusion: Our study concluded that tumour related factors, biologic and imagistic findings such as tumour stage, lymph node, tumour differentiation grade and CEA levels can be used as parameters for predicting the tumour response following neoadjuvant therapy.

Key words: rectal cancer, neoadjuvant, chemoradiotherapy, predictive parameters, clinical response

\section{Introduction}

The GLOBOCAN study estimates that there will be approximately 18 million new cancer patients in 2018 and one third of them will be consisted of lung, breast and colorectal cancer. Colorectal cancer represents the second cause of death after lung cancer (1). Out of all colorectal cancer one third is represented by rectal cancer. Rectal cancer treatment strategies have changed over the years, from postoperative chemoradiotherapy considered as the principal therapy for stage II-III $(2,3)$, to the introduction of TME (3), and nowadays neoadjuvant chemoradiotherapy being considered as mandatory for stage IIIII rectal cancer (4). Furthermore, a more tailored approach to rectal cancer treatment can lead to the development of other strategies such as: transanal endoscopic microsurgery or nCRT followed by close surveillance.

Tumour response to neoadjuvant therapy can be evaluated prior to surgery through the clinical response rate, clinical complete response (cCR) representing no more evidence of tumour presence, or it can be evaluated through the pathologic response grading system in which a pathologic complete response ( $\mathrm{pCR}$ ) represents tumour absence in the surgical specimen. Obtaining a pCR has been associated with better disease-free survival rates (DFS), better sphincter preservation and improved local control (5-8). Rectal tumours have a heterogenous response to $\mathrm{nCRT}$, pCR rates can vary from 15 to $30 \%$ $(9,10)$. Clinical complete response has been proven with an almost twice rate rate $(11,12)$. Patients can respond to nCRT either with a pathologic complete response, tumour downstaging or with no respond and developing of distant metastasis. Randomized trials proved a $25 \%$ rate of distal metastasis for patients treated with nCRT and TME (13-15). There is no consensus of independent parameters that can be used for predicting pCR and current research, although it is performed from a retrospective point of view, is aiming to clarify this topic. The utility of these factors would lead to a more personalized strategy and could help to reduce the number of 
unresponsive patients exposed to unnecessary neoadjuvant therapy and its toxicity, could improve surgical morbidity by performing surgical procedures on patients that hadn't been irradiated prior, could help obtain better financial costs, and help improve overall quality of life for rectal cancer patients. On the other hand, the responders would be better classified and thus could benefit from a more tailored approach.

Our goal was to evaluate the parameters that could predict the tumour response to neoadjuvant therapy for patients with rectal cancer.

\section{Method}

We performed a retrospective study and reviewed the medical documentation for patients that received treatment for rectal cancer in our surgical department between 2014-2018 following neoadjuvant chemoradiotherapy. We excluded patients that had other malignant disease, or metastatic dissemination. Data was collected regarding patient demographics, rectal exam, clinical staging, CEA levels, surgical procedure, pathological findings and follow up. Surgical procedure was performed either through open or laparoscopic approach and consisted of anterior resection or abdomino-perineal resection. Patients received long course neoadjuvant chemoradiotherapy with 5 fluorouracil and radiotherapy of $50.4 \mathrm{~Gy}$ delivered in 28 fractions. Our goal was to evaluate the possibility of predicting the tumour response using parameters that could be obtained prior to surgery and correlating their value with the pathology report. The premise being that by identifying factors that could predict tumour response it could lead to a better classification and optimisation of the therapeutic strategy. A total of 98 patients were included in this study. Follow up varied from 24 to 60 months. The tumour regression AJCC criteria (16) was used. A complete response is equivalent to a tumour regression score of 0 (TRG0) with no viable cancer cells present, TRG1 represents a near complete response and consists of single cells or rare small groups of cancer cells remaining, TRG2 represents a partial response and consists of residual cancer with evident tumour regression but more than single cells or rare small groups of cancer cells, TRG3 represents poor or no response and consists of extensive residual cancer with no evident tumour regression. CEA levels were obtained prior to neoadjuvant therapy, prior to surgery and at follow up and were considered either normal $<5 \mathrm{ng} / \mathrm{mL}^{3}$ or elevated $>5 \mathrm{ng} / \mathrm{mL}^{3}$. Overall survival rate (OS) and disease-free survival rate (DFS) were used throughout the follow up. Clinical $\mathrm{T}$ and clinical $\mathrm{N}$ stage $(\mathrm{cT}$ and $\mathrm{cN})$ were defined as $\mathrm{T}$ and $\mathrm{N}$ stage prior to treatment. Staging was defined according to the guidelines criteria used at the time of the treatment. Patients were staged using MRI or CT according to the possibilities at the time of the treatment. Endoscopy was used for preoperative diagnosis or postoperative surveillance and was performed in our clinic by two surgeons. All surgical procedures were performed in our clinic and according to the guidelines at the time of the treatment. The rectum was defined as the surgical rectum and it's fractions were defined in $\mathrm{cm}$ starting from the external anal orifice as seen on the endoscope as follows : upper rectum $11-15 \mathrm{~cm}$, middle rectum $6-10 \mathrm{~cm}$, low rectum $1-5 \mathrm{~cm}$. All surgical procedures were R0 and the TME resection was complete according to the Quirke protocol (Intact mesorectum with only minor irregularities, no defects deeper than $5 \mathrm{~mm}$, no coning toward the distal margin of the resection, smooth $\mathrm{CRM}$ on transverse sections). All patients had imagistic procedures performed both for staging and then preoperative. The Kaplan-Meier curve was used for the OS and DFS, and statistical analysis was performed using GraphPad Prism version 7.00 for Windows, GraphPad Software, La Jolla California USA, www.graphpad.com.

\section{Results}

A total of 98 patients were included in the study. 66 patients were males (67.3\%) and 32 
were females (32.7\%). The mean age was 64.6 (39-87). The majority of patients were form an urban area $(69 \%)$ compared to $31 \%$ from a rural area. The 48 months overall survival rate was $81.63 \%$ and the 48 months diseasefree survival rate was $69.38 \%$. Clinical $\mathrm{T}$ staging: cT0 2 patients (2.04\%), cT1 6 patients (6.12\%), cT2 10 patients $(10.2 \%)$ and cT3 69 patients $(70.4 \%)$ and cT4 11 patients (11.22\%). Clinical N staging was represented as follows: 21 patients cN0 $(21.42 \%), 35$ patients cN1(35.71\%) and 42 patients cN2 (42.85\%). 87 patients were graded stage II and III (88.77\%). G grading: G1 12 patients (12.24\%), G2 60 patients $(61.22 \%)$, G3 18 patients $(18.36 \%)$ and G4 8 patients $(8.16 \%)$. The patient's characteristics are shown in Table 1. According

Table 1. Patients general characteristics

\begin{tabular}{lc}
\hline Patients general characteristics & $\begin{array}{c}\text { No of patients } \\
\mathbf{N}=98\end{array}$ \\
\hline Sex & $66(67.3 \%)$ \\
Men & $32(32.7 \%)$ \\
Women & $64.6(29-87)$ \\
\hline Age & \\
\hline Clinical T stage & $2(2.04 \%)$ \\
cT0 & $6(6.12 \%)$ \\
cT1 & $10(10.2 \%)$ \\
cT2 & $69(70.4 \%)$ \\
cT3 & $11(11.22 \%)$ \\
CT4 & \\
\hline Clinical N stage & $21(21.42 \%)$ \\
cN0 & $35(35.71 \%)$ \\
cN1 & $42(42.85 \%)$ \\
CN2 & \\
\hline Clinical Stage & $11(11.22 \%)$ \\
Stage 0-I & $87(88.77 \%)$ \\
Stage II-I & \\
\hline G stage & $12(12.24 \%)$ \\
G1 & $60(61.22 \%)$ \\
G2 & $18(18.36 \%)$ \\
G3 & $8(8.16 \%)$ \\
G4 & \\
\hline TRG grading & $25(25.51 \%)$ \\
TRG 0 & $36(36.73 \%)$ \\
TRG 1 & $24(24.48 \%)$ \\
TRG 2 & $13(12.74 \%)$ \\
\hline Tumour location & \\
Upper rectum & $11(11.22 \%)$ \\
Middle rectum & $33(33.67 \%)$ \\
Lower rectum & $54(55.10 \%)$ \\
\hline & \\
\hline & \\
\hline
\end{tabular}

to the TRG score the patients were divised into 4 groups: TRG0 25 patients (25.51\%), TRG 1 36 patients $(36.73 \%)$, TRG 224 patietns (24.48\%) and TRG 313 patients (12.74\%). There were no significant differences regarding age, sex, or comorbidities between the TRG groups of patients.

Tumour grading was considered statistically significant for both TRG0 and TRG3 groups. The tumours most likely to respond to neoadjuvant therapy were G1 or G2 with a $24 \%$, and $64 \%$ for TRG0 and $7.69 \%, 30.7 \%$ for TRG3, $\mathrm{p}=0.0243$ and 0.0030 . And similarly, tumours that did not respond well to neoadjuvant therapy were $\mathrm{G} 3$ and $\mathrm{G} 4,12 \%$ of them for TRG0 and $61.53 \%$ for TRG3. T4 tumours were more likely not to achieve pCR (4\%) compared to lesser T stages, for the TRG3 group T4 tumours being the most represented category (46.15\%). Clinical N stage reported a better TRG score for N0,N1 patients compared to N 2 patients $(40 \%, 52 \%$, vs $8 \%) \mathrm{p}=0.0074$ and $\mathrm{p}=0.0004$ and amongst TRG 3 group the most likely not to respond to nCRT were the N2 patients $(53 \%)$ compared to N0 and N1 $(15.38 \%$ and $30.76 \%) p=0.0405$ and $p=0.0250$. Elevated CEA levels were a negative predictor for a good response to $\mathrm{nCRT}$, with elevated levels ratio for TRG0 being lesser then for TRG 3, $28 \%$ vs $69.23 \%$.

\section{Discussions}

Our study aimed to find parameters that could be used to predict tumour response to neoadjuvant therapy. Our results associated tumour related factors and biological findings with a degree of tumour regression, such as clinical tumour stage, clinical lymph node, tumour differentiation grade and CEA levels.

TRG0 is associated with a better OS and DFS, compared to TRG 3, for a mean follow up of 36 months. The DFS was significantly higher for TRG 0 and decreasing for every other group of TRG (88.8\% TRG0, 86.10\% TRG 1, $79.10 \%$ TRG2 and $69.10 \%$ TRG3). The Kaplan-Meier OS and DFS rates are shown in Fig. 1, 2, 3. A meta-analysis of 16 studies with a total patient number of over 3000 estimated 


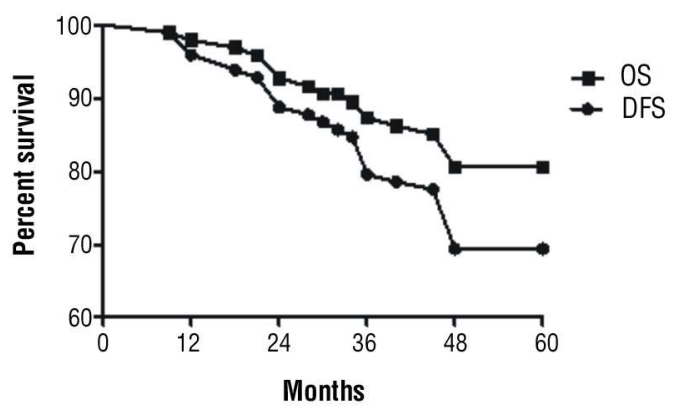

OS - Overall survival rate DFS - Disease-free survival rate

Figure 1. Kaplan-Meier OS vs DFS curve

a better OS rate and lower local recurrence rates associated with $\mathrm{pCR}$ (OR $0.23 \mathrm{p}<0.001$ and $\mathrm{OR}=0.25 \mathrm{p}=0.002$ ) (17). Other studies reported better DFS and OS rates for patients developing $\mathrm{pCR}$ or even intermediate levels of pathological response $(18,19)$. Although numerous studies focus on establishing the pCR rate, a consensus is yet to be obtained regarding the factors that could predict it. Even the TRG score has several proposed gradings systems such as the Mandard score, the Dworak scale, the Rodel percentage model, the Aberdeen/Murray residual percentage model, the AJCC score (16,20-23). Tumour size has been considered as a pCR predictive factor in other studies, Garland et al (24) analysed a group of 297 patients and reported that tumour size is an independent predictor for pCR. Another study published in 2016 analysed clinical predictive factors for locally advanced rectal cancer and concluded that tumour size $<5 \mathrm{~cm}$ is a predictive factor for positive $\mathrm{pCR}$ and also showed a positive trend for nodal status and pCR (25). A large study, $\mathrm{n}>13.000$ patients focussed on evaluating factors associated with tumour response, concluded that lower tumour stage and grade, negative lymph nodes, CEA normal levels, association of chemotherapy and increased doses of radiotherapy can induce a greater regression (26). nCRT, especially for locally advanced rectal cancer has improved local control of the disease, and managed to reduce LR rates, but the distant metastasis rate

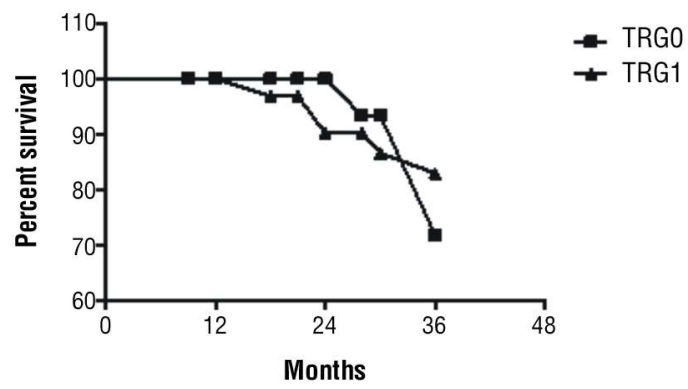

TRGO - OS for TRGO group OS - Overall survival rate TRG1 - OS for TRG1 group TRG - Tumour regresion grade

Figure 2. Kaplan-Meier OS curve for TRGO and TRG 1 group

remains higher for this group of patients. Survival rates could be improved for locally advanced rectal cancer patients by a better understanding and treatment of the disseminated disease. Adjuvant therapy is directly involved in this matter, however by failing to identify the patients at risk of developing distal metastasis following nCRT +TME and treating them all with adjuvant chemotherapy would lead to unnecessary overexposure for the majority of $75 \%$ patients that will not develop distant metastasis. Basically, the patients with a higher risk for disease recurrence represent the candidates for adjuvant chemotherapy. TRG score is not always associated with lymph node regression, and studies reported a 7\% lymph node invasion remnant even when there is a TRG0 for the primary tumour (27).

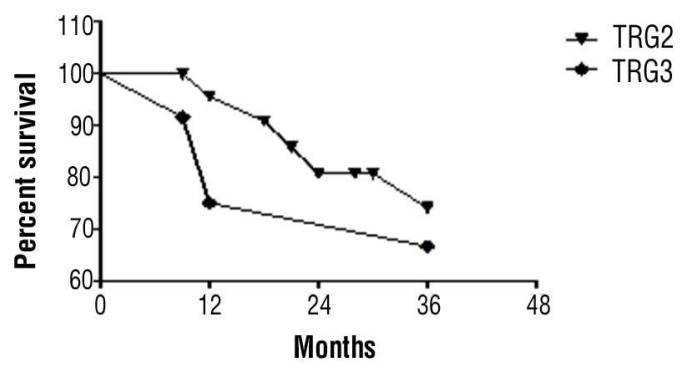

$\begin{array}{ll}\text { TRG2 - OS for TRG2 group } & \text { OS - Overall survival rate } \\ \text { TRG3 - OS for TRG3 group } & \text { TRG - Tumour regresion grade }\end{array}$

Figure 3. Kaplan-Meier OS curve for TRG2 and TRG 3 group 
Which raises the questions: Is the degree of tumour response more significant than the ypTNM staging? Could the tumour response reflect the overall therapeutic response better than the yp staging? The NAR score which is calculated using cT and pathological $\mathrm{T}$ and $\mathrm{N}$ degrees standardises the $\mathrm{nCRT}$ response into two categories Recent studies validated the predictive value of the NAR score regarding DFS, (28) and concluded that it can even have better value than the $\mathrm{pCR}$ in predicting OS (29). Another NAR study that was published this year addressed the relation between the NAR score and the indication for adjuvant therapy and concluded that patients in the low NAR group $(<16)$ that received neoadjuvant therapy had a better prognostic, suggesting that adjuvant chemotherapy could improve survival for patients with a better therapeutic effect of the neoadjuvant therapy (30).

Studies in the field of molecular profiling, immunotherapy, biomarkers or tumour pattern of response represent alternative strategies for establishing parameters that could predict tumour response, however they depend on the surgical specimen. Patients that are MSI+ (test positive for microsatellite instability) are prone to a poorer prognosis (31), and it is considered that this prognosis may be associated to a reduced response to the neoadjuvant therapy (32). Immunotherapy could prove to be an alternative solution for patients MSI+ that respond poorly to nCRT. A prospective trial studying the effect of the pembrolizumab PD-1 (programmed death) blocker, revealed a $40 \%$ response rate for colorectal cancers (33). DNA mutations - KRAS and p53 mutations are considered to confer some degree of tumour resistance to radiotherapy $(34,35)$. Further DNA mutations studied like the apoptotic LUM genes and the DNA repair gene XRCC3 and SMC1 have been reported to decrease the response to nCRT $(36,37)$. The tumour patterns of response is of recent interest, the idea that following nCRT the tumour shrinks lumen centred for tumours that have yet to breach the muscularis propria would represent the ideal response, and could easily be evaluated through endoscopy or imagistic strategies. However, it has been postulated that rectal cancer can respond via two ways to nCRT: shrinkage and fragmentation (38). Fragmentation can be present in up to $40 \%$ locally advanced rectal cancer patients (39). The presence of these small groups of tumours cells, can be responsible of less actual downstaging, the presence of positive resection margins, residual positive lymph nodes and overall a poorer outcome.

Finally, the duration between the completion of the neoadjuvant therapy and surgery could have an impact on the tumour regression. All of our procedures were performed between 6 to 8 weeks after neoadjuvant therapy. A recent study published improved pCR results if the interval between neoadjuvant therapy and surgery is greater than 8 weeks (40), other studies proved that this interval represents an independent predictor for $\mathrm{pCR}$ rates $(41,42)$.

\section{Conclusions}

Rectal cancer requires a more patient-centred approach performed in experienced centres. The key to lowering the distant metastasis rate remains in understanding the response to neoadjuvant therapy. We know that the pathologic complete response is a great predictor for good outcomes, however the heterogeneity of tumour response remains challenging. In overcoming this task efforts must be focused on identifying factors capable of predicting the response to nCRT. Response recognition has yet to meet a consensus regarding evaluating methods. Patients could be better stratified if an optimal prediction strategy would be developed. Clinical assessments, imagistic findings and biomarkers have been studied. At the moment, the best method to predict $\mathrm{pCR}$ eludes us. A better understanding of the response pattern, the discovery and utilisation of clinically proven biomarkers are essential and could lead to the development of individualised treatment.

However, clinical practice in concordance with national and international guidelines has 
been well established. Sphincter preserving surgery is dictated by the axial tumour spread, the "watch and wait" strategy is suited for incipient stage tumours but could become dangerous without complete surveillance and patient compliance. A patient centred approach would be ideal but usually multidisciplinary teams, when making decisions in the tumour board, rely on established guidelines. Their decision has a tendency to insert the patients into the guidelines group and continue in a nonpatient centred manner. Standard therapy for rectal cancer, in the locally advanced stages remains the same, neoadjuvant chemoradiotherapy, standardised surgical technique (TME either open or laparoscopic/robotic, regardless of the intent to preserve the sphincter) and adjuvant therapy. Of course a better understanding of the heterogeneity of the tumour response to neoadjuvant therapy is essential and would help in optimising the treatment for rectal cancer, but are we ready and willing to adhere to these future principles just yet? Future prospective randomized trials will probably bring more clarification to this subject.

\section{Conflict of Interest}

The authors declare no conflicts of interests.

\section{References}

1. Bray F, Ferlay J, Soerjomataram I, Siegel RL, Torre LA, Jemal A. Global cancer statistics 2018: GLOBOCAN estimates of incidence and mortality worldwide for 36 cancers in 185 countries. CA Cancer J Clin. 2018;68(6):394-424.

2. Wolmark N, Fisher B, Rockette H, Redmond C, Wickerham DL, Fisher ER, et al. Postoperative adjuvant chemotherapy or BCG for colon cancer: results from NSABP protocol C-01. J Natl Cancer Inst. 1988:80(1):30-6.

3. Heald RJ, Moran BJ, Ryall RD, Sexton R, MacFarlane JK. Rectal cancer: the Basingstoke experience of total mesorectal excision, 1978-1997. Arch Surg. 1998;133(8):894-9.

4. NCCN Clinical Practice Guidelines in Oncology (NCCN Guidelines () Rectal Cancer NCCN.org; 2018. Available at: https://www.nccn.org/ professionals/physician_gls/pdf/rectal.pdf. Accessed June 2018.

5. Capirci C, Valentini V, Cionini L, De Paoli A, Rodel C, Glynne-Jones $\mathrm{R}$, et al. Prognostic value of pathologic complete response after neoadjuvant therapy in locally advanced rectal cancer: long-term analysis of 566 ypCR patients. Int J Radiat Oncol Biol Phys. 2008; 72(1):99-107.

6. Habr-Gama A, Perez R0, Nadalin W, Nahas SC, Ribeiro U, Silva E Sousa AH, et al. Long-term results of preoperative chemoradiation for distal rectal cancer correlation between final stage and survival.
J Gastrointest Surg. 2005;9(1):90-9; discussion 99-101.

7. Wiig JN, Larsen SG, Dueland S, Giercksky KE. Clinical outcome in patients with complete pathologic response (pT0) to preoperative irradiation/chemo-irradiation operated for locally advanced or locally recurrent rectal cancer. J Surg Oncol. 2005;92(1):70-5.

8. Maas M, Nelemans PJ, Valentini V, Das P, Rödel C, Kuo LJ, et al. Long-term outcome in patients with a pathological complete response after chemoradiation for rectal cancer: a pooled analysis of individual patient data. Lancet Oncol. 2010;11(9):835-44.

9. Mehta VK, Cho C, Ford JM, Jambalos C, Poen J, Koong A, et al. Phase II trial of preoperative 3D conformal radiotherapy, protracted venous infusion 5-fluorouracil, and weekly CPT-11, followed by surgery for ultrasound-staged T3 rectal cancer. Int J Radiat Oncol Biol Phys. 2003;55(1):132-7.

10. Yoon SM, Kim DY, Kim TH, Jung KH, Chang HJ, Koom WS, et al. Clinical parameters predicting pathologic tumor response after preoperative chemoradiotherapy for rectal cancer. Int J Radiat Oncol Biol Phys. 2007;69(4):1167-72.

11. Das P, Minsky BD. A watch-and-wait approach to the management of rectal cancer. Oncology (Williston Park). 2013;27(10):962-8.

12. Martens MH, Maas M, Heijnen LA, Lambregts DMJ, Leijtens JWA, Stassen LPS, et al. Long-term outcome of an organ preservation program after neoadjuvant treatment for rectal cancer. J Natl Cancer Inst. 2016;108(12):djw171.

13. Bujko K, Nowacki MP, Nasierowska-Guttmejer A, Michalski W, Bebenek M, Kryj M. Long-term results of a randomized trial comparing preoperative short-course radiotherapy with preoperative conventionally fractionated chemoradiation for rectal cancer. $\mathrm{Br} J$ Surg. 2006;93(10):1215-23.

14. Gérard JP, Conroy T, Bonnetain F, Olivier Bouché, Chapet 0 , Closon-Dejardin MT, et al. Preoperative radiotherapy with or without concurrent fluorouracil and leucovorin in T3-4 rectal cancers: Results of FFCD 9203. J Clin Oncol. 2006;24(28):4620-5.

15. Sebag-Montefiore D, Stephens RJ, Steele R, Monson J, Grieve R, Khanna $S$, et al. Preoperative radiotherapy versus selective postoperative chemoradiotherapy in patients with rectal cancer (MRC CR07 and NCIC-CTG C016): A multicentre, randomised trial. Lancet. 2009;373(9666):811-20.

16. Mace AG, Pai RK, Stocchi L, Kalady MF. American Joint Committee on Cancer and College of American Pathologists regression grade: a new prognostic factor in rectal cancer. Dis Colon Rectum 2015; 58(1):32e44

17. Martin ST, Heneghan HM, Winter DC.Systematic review and metaanalysis of outcomes following pathological complete response to neoadjuvant chemoradiotherapy for rectal cancer. Br J Surg. 2012; 99(7):918-28.

18. de Campos-Lobato LF, Stocchi L, da Luz Moreira A, Geisler D, Dietz DW, Lavery IC, et al. Pathologic complete response after neoadjuvant treatment for rectal cancer decreases distant recurrence and could eradicate local recurrence. Ann Surg Oncol. 2011;18(6):1590-8

19. Rodel C, Martus P, Papadoupolos T, Füzesi L, Klimpfinger M, Fietkau $R$, et al. Prognostic significance of tumour regression after preoperative chemoradiotherapy for rectal cancer. J Clin Oncol. 2005;23(34):8688-96

20. Mandard AM, Dalibard F, Mandard JC, Marnay J, Henry-Amar M, Petiot JF, et al.Pathologic assessment of tumor regression after preoperative chemoradiotherapy of esophageal carcinoma. Clinicopathologic correlations. Cancer. 1994;73(11):2680-6.

21. Dworak 0 , Keilholz L, Hoffmann A. Pathological features of rectal cancer after preoperative radiochemotherapy. Int J Colorectal Dis. 1997;12(1):19-23.

22. Rodel C, Martus P, Papadoupolos T, Fuzesi L, Klimpfinger M, Fietkau $R$, et al. Prognostic significance of tumor regression after preoperative chemoradiotherapyfor rectal cancer. J Clin Oncol. 2005;23(34):8688-96.

23. Brown GT, Cash B, Alnabulsi A, Samuel LM, Murray GI. The 
expression and prognostic significance of bcl-2-associated transcription factor 1 in rectal cancer following neoadjuvant therapy. Histopathology. 2016;68(4):556-66.

24. Garland ML, Vather R, Bunkley N, Pearse M, Bissett IP. Clinica tumour size and nodal status predict pathologic complete response following neoadjuvant chemoradiotherapy for rectal cancer. Int J Colorectal Dis. 2014;29(3):301-7.

25. De Felice F, Izzo L, Musio D, Magnante AL, Bulzonetti N, Pugliese F et al. Clinical predictive factors of pathologic complete response in locally advanced rectal cancer. Oncotarget 2016;7(22):33374-80.

26. Gash KJ, Baser 0, Kiran RP. Factors associated with degree of tumor response to neo-adjuvant radiotherapy in rectal cancer and subsequent corresponding oucomes. Eur J Surg Oncol. 2017; 43(11):2052-2059.

27. Nagtegaal ID, Marijnen CAM. The future of TNM staging in rectal cancer; the era of neoadjuvant therapy. Current Colorectal Cancer Reports 2008:4:147-54

28. Valentini V, van Stiphout RG, Lammering G, Gambacorta MA,Barba MC, Bebenek M, et al. Nomograms for predicting local recurrence, distant metastases, and overall survival for patients with locally advanced rectal cancer on the basis of European randomized clinical trials. J Clin Oncol. 2011;29(23):3163-72.

29. Yothers G, George TJ, Allegra CJ, Bosset JF, Bujko K, Collette L, et al. Predictive validity of neoadjuvant rectal (NAR)score and pathologic complete response (ypCR) for overall survival (OS) as surrogate endpoints in rectal cancer clinical trial. J Clin Onco 34(Suppl 15): 3533,2017.

30. Maeda K, Shibutani M, Tachimori A, Nishii T, Aomatsu N, Fukuoka T, Nagahara H, Otani H, Inoue T, Ohira M. Prognostic Significance of Neoadjuvant Rectal Score and Indication for Postoperative Adjuvant Therapy in Rectal Cancer Patients After Neoadjuvant Chemoradiotherapy. In Vivo.2020;34(1):283-289.

31. Samowitz WS, Curtin K, Wolff RK, Tripp SR, Caan BJ, Slattery. ML Microsatellite instability and survival in rectal cancer. Cancer Causes Control. 2009;20(9):1763-8.

32. Hasan S, Renz P, Wegner RE, Finley G, Raj M, Monga D, et al Microsatellite instability (MSI) as an independent predictor of pathologic complete response (PCR) in locally advanced recta cancer: a National Cancer Database (NCDB) Analysis. Ann Surg 2020;271(4):716-723
33. Le DT, Uram JN, Wang H, Bartlett BR, Kemberling H, Eyring AD, et al. PD-1 blockade in tumors with mismatch-repair deficiency. $\mathrm{N}$ Engl J Med. 2015;372(26):2509-20.

34. Pettit C, Walston S, Wald P, Webb A, Williams TM. Molecular profiling of locally-advanced rectal adenocarcinoma using microRNA expression (review). Int J Oncol. 2017;51(2):393-404.

35. Bernhard EJ, Stanbridge EJ, Gupta S, Gupta AK, Soto, VJ Bakanauskas, et al. Direct evidence for the contribution of activated $\mathrm{N}$-ras and $\mathrm{K}$-ras oncogenes to increased intrinsic radiation resistance in human tumor cell lines. Cancer Res. 2000; 60(23):6597-600.

36. Agostini M, Zangrando A, Pastrello C, D'Angelo E, Romano G, Giovannoni $R$, et al. A functional biological network centered on XRCC3: a new possible marker of chemoradiotherapy resistance in rectal cancer patients. Cancer Biol Ther. 2015;16(8):1160-71.

37. Conde-Muino R, Cuadros M, Zambudio N, Segura-Jiménez I, Cano C, Palma P. Predictive biomarkers to chemoradiation in locally advanced rectal cancer. Biomed Res Int. 2015;2015:921435.

38. Lopes-Ramos CM, Habr-Gama A, de Souza Quevedo B, Felício NM, Bettoni F, Koyama FC, et al. Overexpression of miR-21-5p as a predictive marker for complete tumor regression to neoadjuvant chemoradiotherapy in rectal cancer patients. BMC Med Genomics. 2014;7:68.

39. Gosens MJ, Klaassen RA, Tan-Go I, Rutten HJ, Martijn H, van den Brule AJ, et al. Circumferential margin involvement is the crucial prognostic factor after multimodality treatment in patients with locally advanced rectal carcinoma. Clin Cancer Res. 2007;13(22 Pt 1):6617-23.

40. Du D, Su Z, Wang D, Liu W, Wei Z. Optimal interval to surgery after neoadjuvant chemoradiotherapy in rectal cancer: a systematic review and meta-analysis. Clinical Colorectal Cancer. 2018;17(1): 13-24.

41. Bitterman DS, Resende Salgado L, Moore HG, Sanfilippo NJ, Gu P, Hatzaras I, et al. Predictors of complete response and disease recurrence following chemoradiation for rectal cancer. Front Oncol. 2015;5:286.

42. Martin ST, Heneghan HM, Winter DC. Systematic review and metaanalysis of outcomes following pathological complete response to neoadjuvant chemoradiotherapy for rectal cancer. Br J Surg. 2012; 99(7):918-28. 